\title{
Effect of altitude on COVID-19 mortality in Ecuador: an ecological study
}

\author{
Adriana Campos ${ }^{1 *}$, Bridget Scheveck', Jeegan Parikh', Santiago Hernandez-Bojorge ${ }^{1}$, Enrique Terán² and
} Ricardo Izurieta'

\begin{abstract}
Background: The SARS-CoV-2/COVID-19 pandemic has claimed nearly 900,000 lives worldwide and infected more than 27 million people. Researchers worldwide are studying ways to decrease SARS-CoV-2 transmission and COVID19 related deaths. Several studies found altitude having a negative association with both COVID-19 incidence and deaths. Ecuadorian data was used to explore the relationship between altitude and COVID-19.

Methods: This is an ecological study examining province-level data. To explore a relationship between altitude and COVID-19, this study utilized publicly available COVID-19 data and population statistics. ANOVA, correlation statistics, and a multivariate linear model explored the relationship between different Ecuadorian altitudes against incidence, mortality, and case-fatality rates. Population statistics attributed to COVID-19 were included in the linear model to control for confounding factors.
\end{abstract}

Results: Statistically significant differences were observed in the regions of Amazónica, Sierra, Costa of Ecuador for incidence, mortality, and case fatality rates, suggesting an association between altitude and SARS-CoV-2 transmission and COVID-19 disease severity ( $p$-value $\leq 0.05$ ). In univariate analysis, altitude had a negative association to mortality rate with a 1 -unit change in altitude resulting in the decrease of 0.006 units in mortality rate ( $p$-value $=$ 0.03). The multiple linear models adjusted for population statistics showed a statistically significant negative association of altitude with mortality rate $(p$-value $=0.01)$ with a 1-unit change in altitude resulting in the decrease in mortality rate by 0.015 units. Overall, the model helped in explaining $50 \%\left(R^{2}=0.4962\right)$ of the variance in mortality rate.

Conclusion: Altitude may have an effect on COVID-19 mortality rates. However, based on our model and R² value, the relationship between our variables of interest and COVID-19 mortality may be nonlinear. More research is needed to understand why altitude may have a protective effect against COVID-19 mortality and how this may be applicable in a clinical setting.

Keywords: SARS-CoV-2, COVID-19, Epidemiological study, Mortality rates, Ecological factor, Altitude

\section{Background}

SARS-CoV-2 was identified in China towards the end of 2019 when a cluster of acute respiratory tract infections occurred in the Hubei providence. During the initial outbreak, the virus was discovered to cause

\footnotetext{
* Correspondence: elba@usf.edu

${ }^{1}$ University of South Florida, 4202 E Fowler Ave, Tampa, FL 33620, U.S.

Full list of author information is available at the end of the article
}

an acute respiratory syndrome, named coronavirus disease 2019 (COVID-19), mostly affecting the elderly (i.e., over 60 years of age) and individuals with underlying health conditions $[1,2]$. However, the viral mode of transmission and globalization allowed this regional outbreak to spread throughout the world. By the spring of 2020, SARS-CoV-2 was present in every continent excluding Antarctica [3]. At the time this

(c) The Author(s). 2021 Open Access This article is licensed under a Creative Commons Attribution 4.0 International License, which permits use, sharing, adaptation, distribution and reproduction in any medium or format, as long as you give appropriate credit to the original author(s) and the source, provide a link to the Creative Commons licence, and indicate if changes were made. The images or other third party material in this article are included in the article's Creative Commons licence, unless indicated otherwise in a credit line to the material. If material is not included in the article's Creative Commons licence and your intended use is not permitted by statutory regulation or exceeds the permitted use, you will need to obtain permission directly from the copyright holder. To view a copy of this licence, visit http://creativecommons.org/licenses/by/4.0/ The Creative Commons Public Domain Dedication waiver (http://creativecommons.org/publicdomain/zero/1.0/) applies to the data made available in this article, unless otherwise stated in a credit line to the data. 
article was written, SARS-CoV-2 has infected more than 27 million individuals worldwide and has caused nearly 900,000 deaths [4]. From viral transmission mechanisms [5-8] to COVID-19 treatments [9], researchers are attempting to better understand the disease dynamics and reduce its burden on mankind. The global spread of COVID-19 cases drives research to attempt to understand how environmental factors may contribute to SARS-CoV-2 transmission and COVID-19 disease severity [5, 7, 10-14].

One ecological factor suggesting an effect on viral transmission and disease severity is altitude [14-17]. There is growing body of evidence indicating altitude may have an effect on disease incidence $[17,18]$ as well as overall viral integrity $[14-16,19,20]$. One study in particular illustrated a distinct decrease in COVID-19 affected populations above $3000 \mathrm{~m}$ above sea level (masl) [14]. Furthermore, an Indian study found a similar conclusion [16]. While the two aforementioned studies focused on disease incidence and altitude, there are also studies examining viral properties that may be affected by higher altitudes [15, 20]. This associated decrease may be due to biological factors in susceptible humans, environmental factors affecting SARS-CoV-2 and its transmission dynamics, or perhaps a combination of both. Moreover, these studies propose a negative correlation between altitude and disease incidence.

There are few studies investigating the effect altitude may have specifically on COVID-19 mortality $[21,22]$. Of the two studies found, both offer different conclusions, indicating a need for additional research. One of the studies, conducted in Peru, found high altitude reduced SARS-CoV-2 infection rate, yet the case fatality rate (CFR) was not affected by altitude [21]. However, a letter to the editor addressing the aforementioned study suggests their conclusion may be due to differences in regional testing rates [23]. Another study examining the CFRs in United
States and Mexican residents living at different altitudes concluded the CFR was only statistically lower in men younger than 65 years of age [22]. It is evident additional research is required to further explore the relationship between altitude and COVID-19 mortality.

During the early stages of the COVID-19 pandemic, Ecuador became one of the hardest hit South American countries, having one of the highest case fatality rates in the world [24]. Its first case, confirmed in February 2020, appeared in its largest city, Guayaquil, and shortly thereafter cases started appearing in the rest of the Ecuadorian provinces [25-27]. By the end of August 2020, nearly 100,000 cases and 10,000 deaths were confirmed [28]. Ecuador's high caseload and large altitudinal range provide the perfect setting to explore communities living at different altitudes during this pandemic. This study aims to explore how COVID-19 mortality statistics may be affected by altitude (Fig. 1).

\section{Methods \\ Study setting and design}

Ecuador, the setting of our study, contains numerous ecological regions ranging from Galapagos Islands to the Amazónica. The provinces are categorized into four regions of Amazónica, Sierra [Highlands], Costa, and Insular [Galapagos Islands]. In addition to its ecological diversity, Ecuador is home to populations living in areas ranging from sea-level to $3000+$ meters in altitude. Ecuadorian regions are mostly divided on altitude/ecological level, with provinces categorized as "Costa" falling between 50 to 1000 masl, "Sierra" 800 to 3900 masl, "Amazónica" 500 to 1500 masl, and "Insular" masl.

This is an ecological study, conducted using Ecuadorian province-level data on COVID-19 case counts and deaths from February 2020 until August 2020. All the provinces $(n=23)$, except for the Galapagos Islands ("Insular") were included in the study.

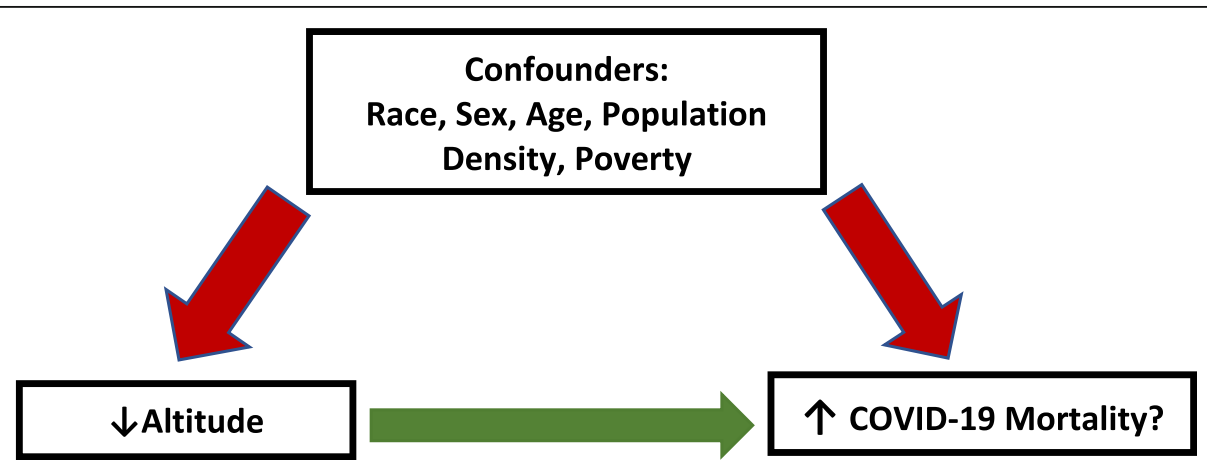

Fig. 1 Operationalization of the research question in relation to the covariates. In this figure we show the relationship the potential confounders have on altitude and COVID-19 mortality 


\section{Study data}

All the data used in the study was publicly available and extracted manually from the Ecuadorian Ministry of Public Health COVID-19 bulletin [MOH] and Ecuadorian National Institute for Statistics and Censuses [INEC]. Information relating to COVID-19, such as the number of confirmed cases and deaths per provinces was extracted from the MOH monthly COVID-19 bulletin [28]. All the variables showing relevance to COVID-19 transmission based on current literature and being available at provincial level were included in the study. Due to last census taking place in 2010, the INEC census estimates for 2020 were used. Statistics on poverty, sex, population density, age groups, race, and hospital beds per 1000 persons were taken from INEC database [29]. The estimates of each of the sociodemographic covariates were calculated by using 2010 covariate proportions on 2020 INEC census estimates. The healthcare resource availability proxy (i.e., hospital beds per 1000 persons) was directly from INEC 2020 data. As wide ranges of altitudes are possible for each of the provinces, the altitude of each province's capital was used, assuming a significant portion of each province's population would be in the capital as well as most of the province hospitals. All the provincial-level data were collated and input in a single excel file. None of the variables from the two data sources had any missing variables.

\section{Statistical analysis}

From the COVID-19 case and death counts data incidence, mortality, and case-fatality rates were calculated on the provincial level. We initially computed basic descriptive statistics on regions with provinces as unit of analysis. Due to natural categorization of provinces, a high degree of collinearity existed between region and altitudes of provinces. An ANOVA conducted comparing altitude to region further confirmed this assumption with all regions being statistically different and therefore allowing the use of regions as a valid proxy for altitude for the ANOVA. The ANOVA procedure was used to compare the regional differences in incidence, mortality, and case-fatality rates. It was also run to compare the regional differences in independent variables and other covariates. Due to Insular region having just one province, to determine a better fit, an ANOVA procedure was done with and without its inclusion and therefore, the subsequent analyses excluded this region. Univariate procedures to examine the incidence, mortality, and CFRs distributions were conducted. Due to the covariate data being related specifically to the population and not to outcome, CFR was not deemed appropriate to create exploratory models, and therefore, the model outcome of interest was mortality rate.

Initially, correlation statistics was conducted on all covariates against mortality rate. Based on the results of the regional ANOVA analysis and the correlation statistics, a multilinear modeling was conducted. The model aimed to explore if altitude could explain the differences in regional mortality rates. As altitude was the main area of interest, we excluded region in the final model to avoid instability created by the high intercorrelation between region and altitude. The initial regression model included sociodemographic variables. To account for healthcare resource availability the hospital beds per 1000 persons 2020 estimates were added to the initial model. Based on the results of the sequential regression models, the final model controlled for population density, proportion of males, level of poverty, proportion of people above the age of 55 years, and race. Covariates listed were included due to its significance in the literature as potential confounders for COVID-19 mortality, regardless of the level of statistical significance in either correlation statistics or model. We then assessed homoscedasticity and the distribution of the residuals to determine if the assumptions of multiple linear regression were met. Statistical significance was defined as having a $p$-value less than or equal to 0.05 . All the data was analyzed using $\mathrm{SAS}^{\circ}$ 9.4 software [30].

\section{Results}

\section{Basic descriptive statistics and ANOVA}

Twenty-three Ecuadorian provinces in three regions were analyzed ( $n=11$ Sierra, $n=6$ Costa, $\mathrm{n}=6$ Amazónica). Table 1 indicates the regional differences found in the independent variables. Altitude and the population over 55 years old were the most statistically different between regions ( $p$-value $<0.0001$ ), while poverty, sex, population density, and race were significant at $\mathrm{p}$-value $<0.05$. Hospital beds per 1000 persons was not statistically significant.

Regional differences were observed for mortality (Fig. 2), case-fatality, and incidence rates (Table 2). The Amazónica mortality rate mean was 29.96 per 100,000 , the Costa

Table 1 Regional wise differences in independent variables

\begin{tabular}{llll}
\hline Covariates & Costa & Amazónica & Sierra \\
\hline Altitude (masl) ** & 21 & 694.17 & 2408.18 \\
Poverty (\%) * & 71.07 & 78.28 & 61.06 \\
Male (\%) * & 51.09 & 51.89 & 44.86 \\
Population above 55 years of age (\%) ** & 12 & 8.69 & 14.58 \\
Population density* & 106.17 & 6.50 & 94.64 \\
Race (\%) & & & \\
$\quad$ Indigenous & 1.15 & 34.27 & 14.14 \\
$\quad$ Afro Ecuadorian & 13.53 & 2.76 & 3.31 \\
$\quad$ Montubio & 12.61 & 0.60 & 0.92 \\
$\quad$ Mestizo & 65.91 & 58.79 & 77.67 \\
$\quad$ White & 6.1 & 3.29 & 3.79 \\
Other & 0.67 & 0.28 & 0.16 \\
Hospital beds per 1000 persons & 1.15 & 1.20 & 1.35 \\
\hline
\end{tabular}

${ }^{*} p$-value $<0.05 * *$ p-value $<0.0001$ Measured by F-test (ANOVA) 


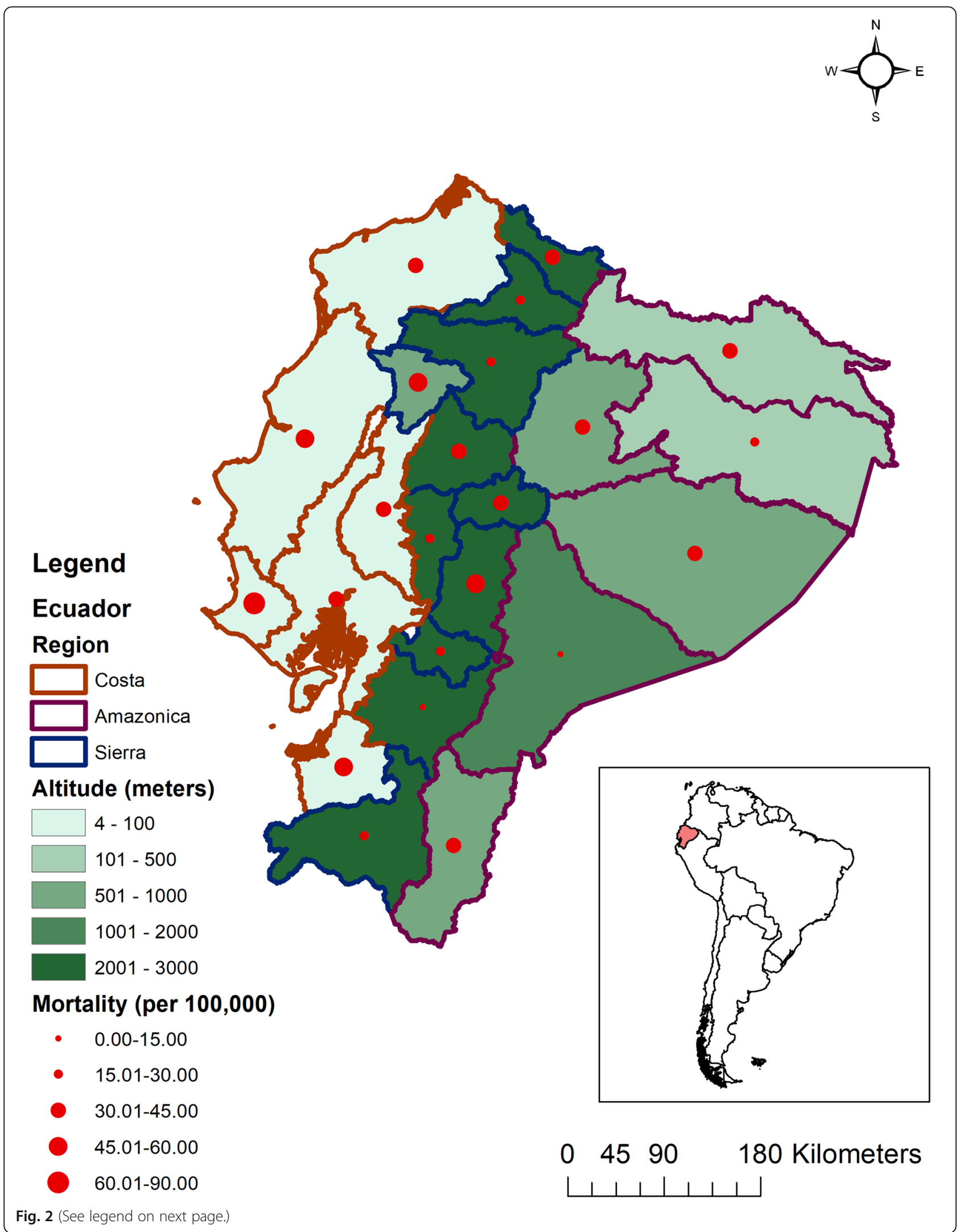


(See figure on previous page.)

Fig. 2 Provincial COVID-19 mortality rates and altitudes, Ecuador. In this map of Ecuador, the provinces with brown borders represent Costa region, blue borders Sierra region, and purple borders Amazónica region. The provinces are divided in five categories based on the altitude of the capital of those provinces in meters and are represented in light to dark green. Mortality rates due to COVID-19 in each of the provinces were categorized into five levels $(0-15,15-30,30-45,45-60,60-90)$ and are presented with ascending size of red dots. The right lower corner shows a map of South America with Ecuador highlighted in red

mean was 49.46 per 100,000 , and the Sierra regional mean was 30.96 per 100,000. The ANOVA result for mortality rates between regions was statistically significant ( $p$ value $=0.05$, F-test $=3.44, \mathrm{df}=22)$. None of the individual regional comparisons were statistically significant (e.g., Sierra versus Costa, etc.). The CFR means for Amazónica, Costa, and Sierra were 2.97, 11.94, and 5.19 per 100 cases respectively. The regional CFR was significantly different $(p$-value $=0.01, \mathrm{~F}$-test $=6.71, \mathrm{df}=22)$ and there were statistically significant region comparisons by Costa vs. Sierra and Costa vs. Amazónica ( $p$-value < 0.05). The mean incidence rates for Amazónica, Costa, and Sierra were $1074.86,461.16$, and 628.32 per 100,000 , respectively. The regional incidence rates were significantly different $(p$ value $<0.0001, \mathrm{~F}$-test $=18.64, \mathrm{df}=22$ ), with Amazónica having a significantly higher incidence rate compared to both Costa and Sierra ( $p$-value $<0.05)$.

\section{Correlations}

Correlation statistics between the covariates and the mortality rate were ran to explore any association between both independent and dependent variables that may be important to note in the final linear model. Altitude and Race (Other) were the only two statistically significant correlations to the mortality rate. Altitude showed a negative correlation of $-0.45(p$-value $=0.03)$ and Race (Other) of 0.61 (p-value $=0.002$ ). All other covariates showed small correlations against mortality rate.

\section{Linear model}

When adding healthcare resource availability to the initial model, the difference between $\mathrm{R}^{2}, 0.002$, was not statistically significant, therefore excluded from the final model. The final linear model included population density, proportion of males, poverty level, proportion above 55 years of age, altitude, and Race (White) (Table 3). The model was nonsignificant with a $p$-value of 0.06 and

Table 2 Regional differences in mortality, case fatality, and incidence rate

\begin{tabular}{llll}
\hline Indicator & Costa & Amazónica & Sierra \\
\hline Mortality rate** & 49.45 & 29.96 & 30.96 \\
Case Fatality rate* $^{*}$ & 11.94 & 2.97 & 5.19 \\
Incidence rate* & 461.16 & 1074.86 & 628.32 \\
\hline
\end{tabular}

${ }^{*}$ p-value $<0.05 * * p$-value $=0.05$ Measured by F-test (ANOVA) Note: Mortality rate and Incidence rate are calculated per 100,000 population, while Case Fatality rate is calculated per 100 cases explained $50 \%$ of the variance in mortality rate. Individually, altitude was statistically significant with a p-value of 0.01 . Population density was the next closest to significance at $\mathrm{p}$-value $=0.06$. No other risk factors were statistically significant.

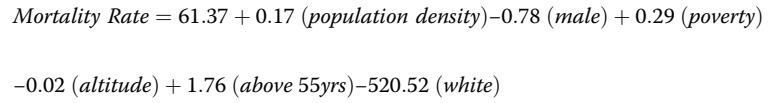

\section{Discussion}

The results from the linear regression analysis clearly indicates altitude as the most statistically significant model variable. This was both the case while analyzing the variable at the univariate and multivariate level. Furthermore, the results from the ANOVA regional analysis, where regions were proxy for different altitudes, further showed a difference between incidence, case-fatality, and mortality rates. Amazónica had the highest incidence yet the lowest case-fatality and mortality rates. Compared to the other regions, Amazónica had the highest poverty level and proportion of males which are believed to be positively associated with higher COVID-19 morbidity and mortality $[31,32]$ and lowest population density, which is associated with lower incidence [31], potentially contradicting our observations. The high incidence rate in the Amazónica region may be explained by case misclassification with reports showing concern for potential dengue cases being diagnosed as COVID-19 [33]. Specifically in Ecuador, dengue misclassification and underreporting is a current concern during the COVID-19 pandemic [34]. This could explain the significantly higher incidence rate in the Amazónica, yet lowest morality statistics. Furthermore, it is well known due to the

Table 3 Univariate and Multivariate co-relations of risk factors with mortality rate

\begin{tabular}{lll}
\hline Risk factor & Univariate Estimates & Multivariate Estimates \\
\hline Altitude & $-0.006^{*}$ & $-0.015^{*}$ \\
Poverty & 0.319 & 0.293 \\
Male & -0.047 & -0.775 \\
Population density & 0.031 & $0.170^{* *}$ \\
Population > 55 years & -0.632 & 1.756 \\
White & 144.087 & $-520.517^{* * *}$
\end{tabular}

${ }^{*} p$-value $<0.05{ }^{* *} p$-value $=0.06{ }^{* * *} p$-value $=0.09$ Measure by F-test (ANOVA) 
lack of sufficient health care facilities in the Amazónica, most morbidity indicators are underreported. However, in this analysis the healthcare resource availability proxy used did not convey statistically significant differences between regions. This may be due to lack of statistical power or the underrepresentation of hospital beds during the COVID-19 pandemic in Ecuador, where there were many provisional beds made for SARS-CoV-2 infected individuals. Conversely, the Costa region held the lowest incidence rate and highest case-fatality and mortality rate. Although the Costa region's mortality rate was not statistically different than the Sierra region, the case-fatality rate was significantly higher. Since casefatality rate is an indicator based on the number of deaths and the number of cases, not taking into account the population, it is important to acknowledge the differences in the number of case deaths varying from region to region. The high CFR in the Costa region may be due to a higher population density than both other regions. For both mortality and case-fatality rates, as the population-density increased so did mortality. The Costa region is home to the most populated Ecuadorian city and filled with both urban and rural communities. This region is then followed by the Sierra, with a similar mix of communities, while the Amazónica region is almost exclusively rural, with very few large cities in the region. However, one of the strongest risk factors found in the literature for COVID-19 mortality, advanced age [2, 32], was significantly the highest in the Sierra region. This could indicate not only altitude differences but also resource-oriented healthcare factors which could explain the higher mortality statistics in the Costa region [35, 36]. However, our chosen proxy for healthcare resource availability failed to demonstrate a difference between regions.

In both the correlation analysis and the linear model, altitude was a protective factor against COVID-19 mortality. Based on standardized estimates, altitude was the factor with the highest effect on mortality rates followed by population density and identifying as White. The rest of the covariates in the model were not statistically significant nor had large effect on mortality rate. While, race (Other) was statistically significant in the correlation analysis, the proportion of the population identifying as "Other" was too small to be clinically relevant. White race fit the model best and therefore included in the model. The healthcare resource availability covariate was nonsignificant in both ANOVA and linear regression models. Deemed COVID-19 risk factors, the covariates lack of significance may be due to lack of statistical power.

Several hypotheses have been proposed as possible explanations for the protective nature of altitude. One hypothesis focuses on the effects of chronic hypoxia in high altitude environments [37]. Specifically, examining the effects of chronic hypoxia on AngiotensinConverting Enzyme 2 (ACE2), the enzyme SARS-CoV-2 binds to enter host cells. Under conditions of chronic hypoxia, Angiotensin-Converting Enzyme 1 (ACE1) is upregulated by Hypoxia Inducible Factor 1 (HIF-1) in human pulmonary artery smooth muscle cells shifting the balance of the oxygen sensitive Renin-Angiotensin System (RAS) away from the vasodilator ACE2 and towards the vasoconstrictor ACE1. This process markedly decreases ACE2 expression in the pulmonary artery smooth muscle cells $[17,18]$. Due to SARS-CoV-2 utilization of the ACE2 receptor for cellular entry, it is hypothesized populations living in constant hypoxia may be less susceptible to SARS-CoV-2 infection. Additionally, HIF-1, activated in chronic hypoxia, may ameliorate a COVID-19 infection [38]. It is also possible that the levels of hypoxia encountered by populations in higher altitudes may have elicited adaptations with the potential to resist SARS-CoV-2 related complications. The hypoxemia may optimize cellular oxygenation, antioxidant systems and mitochondrial performance at the alveolar level [39]. Lastly, high concentrations of erythropoietin (EPO) might protect high altitude residents by stimulating erythropoiesis and heme synthesis and thereby increasing tissue oxygenation [40]. In addition to biological mechanisms that may be affected by living in higher altitudes, environmental factors are also theorized reasons for the observed negative correlation between altitude and COVID-19 mortality. A possible explanation of decreased SARS-CoV-2 infection rates in populations at high altitude is a higher level of $\mathrm{O}_{3}$ (ozone). Considered a disinfecting agent, ozone disrupts the reproductive cycle via peroxidation, affecting virus-to-cell contact and damaging the viral capsid [15, 41]. Further suggesting the potential impact ozone may have on SARS-CoV-2 transmission, one study, conducted in China from January to March 2020, showed a statistically significant negative correlation between ambient average ozone levels and number of confirmed cases [42]. Lastly, another common element found in high altitudes an increase of ultraviolet (UV) radiation. UV radiation was found to effectively eliminate SARS-CoV [43], suggesting a similar effect for SARS-CoV-2. However, studies on this hypothesis are limited and a recent study found no association between UV radiation and COVID-19 cases [44]. In addition to the sterilization effect of UV radiation, UV radiation's effect on Vitamin D production is also an area of interest. Vitamin D is theorized to help maintain a healthy immune system and its deficiency is associated with increased risk of respiratory infectious diseases [45-48]. This is further supported by recent studies examining finding a protective effect of Vitamin $\mathrm{D}_{3}$ against COVID-19 $[49,50]$. 
Studies have demonstrated that high altitudes are correlated with lower air density and greater distance between molecules which may reduce the size of the airborne virus inoculum and the probabilities of dissemination between people [14]. Furthermore, there may be behavioral factors affecting the relationship between COVID-19 mortality and altitude. Numerous other socioeconomic and lifestyle factors could explain the differences seen in regard to the infectivity and mortality in high altitude populations. A recent study found that higher altitude ( $>2133$ masl) might attenuate infection and death in counties of the United States of America. While infection rate did not correlate with population density, deaths per 100,000 showed a positive association with population density at higher altitudes and lower altitudes [51]. Arias-Reyes et al. concluded the incidence of COVID-19 decreases significantly starting at 1000 masl in 23 Latin American countries. The epidemiological model used in this study (SEIR) supported the hypothesis of decreased SARS-CoV-2 virulence in highlands in four South American countries: Argentina, Bolivia, Ecuador, and Peru [52]. There were higher percentages of recovered patients from the highlands when compared to lowlands, suggesting a higher recovery rate in South American territories with higher altitudes (> 1000 masl) [52]. Similarly, a study conducted in Brazil, concluded the COVID-19 relative incidence, the COVID-19 relative death rate, and the air relative humidity $(\mathrm{RH})$ were lower in cities located in higher altitudes $(795<$ altitude $\leq 1135$ masl) compared to other cities with middle $(97<$ altitude $\leq 795$ masl $)$ and low altitudes (altitude $\leq 97$ masl) [53]. Additionally, Thomson et al. provided evidence of a protective effect of altitude from COVID-19 mortality in populations located in cities with 2500 masl. This protection was shown to be independent of poverty levels among the Peruvian population and inversely correlated with the prevalence of hypertension and hypercholesterolemia [54]. Conversely, results of Arias-Reyes et al. did not show significant difference of death-to-case ratio (death/total reported cases) between $<1000$ masl areas when compared to $>1000$ masl areas [52]. Another publication cautioned the researchers against associating altitude to decreased COVID-19 pathogenicity based solely on altitude arguing factors such as population density, access to commodities, clinical care, and ability to "social distance" may all be contributing to the observed reduced pathogenicity [55]. However, the results of our study suggest altitude is an independent protective factor even after considering population density or poverty. Health benefits of communities living in high altitude is not new knowledge, with high altitude associated with higher levels of physical activity, lower rates of obesity, cardiovascular disease, and cancer [56-58].
Limitations in the study mainly include lack of access to smaller unit-sized data and individual data. This study is an ecological study, focusing on province-level data, and should be noted that there may be individual cities that may be influential or leveraging the results. Regardless of the limitations, altitude was significantly protective against COVID-19 mortality rate in both the correlation analysis and final model.

\section{Conclusion}

Altitude was a protective factor against COVID-19 mortality. However, the low $R^{2}$ value suggests a nonlinear relationship between covariates and COVID-19 mortality. While this study used linear regression, other studies explore the nonlinear relationship between environmental factors and COVID-19 mortality [7, 59, 60], possibly finding additional associations. Yet, more research is needed in understanding why populations living in different altitudes may have different disease outcomes. Furthermore, in the Ecuador population there seemed to be a protective factor in COVID-19 mortality and identifying as White. Although not statically significant, this finding may be of clinical relevance and help identify areas of improvement in Ecuadorian healthcare.

\section{Acknowledgements \\ Not applicable.}

Authors' contributions

AC performed data analysis and was the major contributor in writing the manuscript. BS performed a literature review of the subject and was a major contributor of the manuscript. JP cleaned, analyzed, and created the models for the study in addition to being a major contributor in writing the manuscript. SH cleaned, pulled data, and was a major contributor in writing the manuscript. RI and ET were major contributors in the planning and interpretation of the data, as well as contributing to the manuscript.

\section{Funding}

This research did not receive any specific grant from funding agencies in the public, commercial, or not-for-profit sectors.

\section{Availability of data and materials}

The datasets analyzed during the current study are publicly available from the Ecuadorian Ministerio de Salúd Publica national COVID-19 bulletins, https://www.salud.gob.ec/wp-content/uploads/2020/08/INFOGRAFIANACIONALCOVID19-COE-NACIONAL-08h00-25082020.pdf and the Ecuadorian Instituto National de Estadisticas y Censos https://www.ecuadorencifras.gob. ec/estadisticas/.

\section{Declarations}

Ethics approval and consent to participate Not applicable.

\section{Consent for publication}

Not applicable.

\section{Competing interests}

The authors declare that they have no competing interests.

\section{Author details}

${ }^{1}$ University of South Florida, 4202 E Fowler Ave, Tampa, FL 33620, U.S.. ${ }^{2}$ Colegio de Ciencias de la Salud, Universidad San Francisco de Quito, Campus Cumbayá, Diego de Robles s/n, Quito, 170901 Quito, Ecuador. 
Received: 5 February 2021 Accepted: 1 November 2021

Published online: 12 November 2021

\section{References}

1. Zhou P, Yang XL, Wang XG, Hu B, Zhang L, Zhang W, et al. A pneumonia outbreak associated with a new coronavirus of probable bat origin. Nature. 2020:579(7798):270-3. https://doi.org/10.1038/s41586-020-2012-7.

2. Harapan H, Itoh N, Yufika A, Winardi W, Keam S, Te H, et al. Coronavirus disease 2019 (COVID-19): a literature review. J Infect Public Health. 2020; 13(5):667-73. https://doi.org/10.1016/j.jiph.2020.03.019.

3. Astuti I. Ysrafil. Severe acute respiratory syndrome coronavirus 2 (SARS-CoV2): an overview of viral structure and host response. Diabetes Metab Syndr. 2020;14(4):407-12. https://doi.org/10.1016/j.dsx.2020.04.020.

4. Johns Hopkins. COVID-19 dashboard by the Center for Systems Science and Engineering (CSSE) at Johns Hopkins University (JHU) 2020 updated 2020, September 8. Available from: https://coronavirus.jhu.edu/map.html.

5. Wu Y, Jing W, Liu J, Ma Q, Yuan J, Wang Y, et al. Effects of temperature and humidity on the daily new cases and new deaths of COVID-19 in 166 countries. Sci Total Environ. 2020;729:139051. https://doi.org/10.1016/j. scitotenv.2020.139051.

6. World Health Organization. Modes of transmission of virus causing COVID19: implications for IPC precaution recommendations. 2020 2020, March 29.

7. Tosepu R, Gunawan J, Effendy DS, Ahmad OAl, Lestari H, Bahar H, et al. Correlation between weather and Covid-19 pandemic in Jakarta. Indonesia Sci Total Environ. 2020;725:138436. https://doi.org/10.1016/j.scitotenv.202 0.138436 .

8. Eslami H, Jalili M. The role of environmental factors to transmission of SARSCoV-2 (COVID-19). AMB Express. 2020;10(1):92. https://doi.org/10.1186/s13 568-020-01028-0.

9. National Institutes of Health. COVID-19 Treatment Guidelines Panel 2020 [updated 2020, June 11. Available from: https://www.covid19trea tmentguidelines.nih.gov/whats-new/.

10. Sajadi MM, Habibzadeh P, Vintzileos A, Shokouhi S, Miralles-Wilhelm F, Amoroso A. Temperature, humidity, and latitude analysis to estimate potential spread and seasonality of coronavirus disease 2019 (COVID-19). JAMA Netw Open. 2020;3(6):e2011834. https://doi.org/10.1001/jama networkopen.2020.11834

11. Qi H, Xiao S, Shi R, Ward MP, Chen Y, Tu W, et al. COVID-19 transmission in mainland China is associated with temperature and humidity: a time-series analysis. Sci Total Environ. 2020;728:138778. https://doi.org/10.1016/j. scitotenv.2020.138778.

12. Mendez-Arriaga F. The temperature and regional climate effects on communitarian COVID-19 contagion in Mexico throughout phase 1. Sci Total Environ. 2020;735:139560. https://doi.org/10.1016/j.scitotenv.2020.13 9560.

13. Liu J, Zhou J, Yao J, Zhang X, Li L, Xu X, et al. Impact of meteorological factors on the COVID-19 transmission: a multi-city study in China. Sci Total Environ. 2020;726:138513. https://doi.org/10.1016/j.scitotenv.2020.138513.

14. Arias-Reyes C, Zubieta-DeUrioste N, Poma-Machicao L, Aliaga-Raduan F, Carvajal-Rodriguez F, Dutschmann M, et al. Does the pathogenesis of SARSCoV-2 virus decrease at high-altitude? Respir Physiol Neurobiol. 2020;277: 103443. https://doi.org/10.1016/j.resp.2020.103443.

15. Semple JL, Moore GWK. High levels of ambient ozone (O3) may impact COVID-19 in high altitude mountain environments. Respir Physiol Neurobiol. 2020;280:103487. https://doi.org/10.1016/j.resp.2020.103487.

16. Gupta A, Banerjee S, Das S. Significance of geographical factors to the COVID-19 outbreak in India. Model Earth Syst Environ. 2020;6(4):1-9. https:// doi.org/10.1007/s40808-020-00838-2.

17. Zhang R, Wu Y, Zhao M, Liu C, Zhou L, Shen S, et al. Role of HIF-1alpha in the regulation ACE and ACE2 expression in hypoxic human pulmonary artery smooth muscle cells. Am J Physiol Lung Cell Mol Physiol. 2009;297(4): L631-40. https://doi.org/10.1152/ajplung.90415.2008.

18. Hampl V, Herget J, Bibova J, Banasova A, Huskova Z, Vanourkova Z, et al. Intrapulmonary activation of the angiotensin-converting enzyme type 2/ angiotensin 1-7/G-protein-coupled mas receptor axis attenuates pulmonary hypertension in Ren-2 transgenic rats exposed to chronic hypoxia. Physiol Res. 2015;64(1):25-38. https://doi.org/10.33549/physiolres.932861.

19. Pun M, Turner R, Strapazzon G, Brugger H, Swenson ER. Lower incidence of COVID-19 at high altitude: facts and confounders. High Alt Med Biol. 2020; 21(3):217-22. https://doi.org/10.1089/ham.2020.0114.
20. Tang L, Liu M, Ren B, Wu Z, Yu X, Peng C, et al. Sunlight ultraviolet radiation dose is negatively correlated with the percent positive of SARS-CoV-2 and four other common human coronaviruses in the U.S. Sci Total Environ. 2020;751:141816.

21. Segovia-Juarez J, Castagnetto JM, Gonzales GF. High altitude reduces infection rate of COVID-19 but not case-fatality rate. Respir Physiol Neurobiol. 2020;281:103494. https://doi.org/10.1016/j.resp.2020.103494.

22. Woolcott OO, Bergman RN. Mortality attributed to COVID-19 in high-altitude populations. High Alt Med Biol. 2020;21(4):409-16. https://doi.org/10.1089/ ham.2020.0098.

23. Quevedo-Ramirez A, Al-Kassab-Cordova A, Mendez-Guerra C, CornejoVenegas G, Alva-Chavez KP. Altitude and excess mortality during COVID-19 pandemic in Peru. Respir Physiol Neurobiol. 2020:281:103512. https://doi. org/10.1016/j.resp.2020.103512

24. Johns Hopkins. Mortality analyses updated September 10, 2020. Available from: https://coronavirus.jhu.edu/data/mortality.

25. Smith N. Covid-19 in Ecuador: An Exclusive O\&A with Ecuador's Ambassador to the U.S. Direct Relief2020 [Available from: https://www.directrelief.org/202 0/06/covid-19-in-ecuador-an-exclusive-qa-with-ecuadors-ambassador-to-the$\mathrm{u}-\mathrm{s} / \mathrm{s}$

26. Dube $R, J d$ C. Ecuador city beat one of world's worst outbreaks of Covid-19. The Wall Street Journal. 2020 June;30:2020.

27. Cabrera JML. Kurmanaev A. The New York Times: Ecuador's Death Toll During Outbreak Is Among the Worst in the World; 2020 April 23.

28. Ministerio de Salúd Publica. SITUACIÓN NACIONALPOR COVID-19 INFOGRAFÍA N¹80 Inicio 29/02/2020-Corte 25/08/2020 08:00 2020 [Available from: https://www.salud.gob.ec/wp-content/uploads/2020/08/ INFOGRAFIA-NACIONALCOVID19-COE-NACIONAL-08h00-25082020.pdf.

29. Institudo National de Estatisticas y Censos. Estatisticas [Available from: https://www.ecuadorencifras.gob.ec/estadisticas/.

30. SAS Institute Inc. SAS/ACCESS ${ }^{\circledR}$ 9.4. Cary, NC: SAS Institute Inc

31. Patel JA, Nielsen FBH, Badiani AA, Assi S, Unadkat VA, Patel B, et al. Poverty, inequality and COVID-19: the forgotten vulnerable. Public Health. 2020;183: 110-1. https://doi.org/10.1016/j.puhe.2020.05.006.

32. Zhou F, Yu T, Du R, Fan G, Liu Y, Liu Z, et al. Clinical course and risk factors for mortality of adult inpatients with COVID-19 in Wuhan, China: a retrospective cohort study. Lancet. 2020;395(10229):1054-62. https://doi. org/10.1016/S0140-6736(20)30566-3.

33. Centers for Disease Control and Prevention. Is it Dengue or is it COVID-19? 2020 [updated June 24, 2020. Available from: https://www.cdc.gov/dengue/ healthcare-providers/dengue-or-covid.html.

34. Griffin O. 'Dengue kills too' - Latin America faces two epidemics at once. Reuters. 2020 May;12:2020

35. Institudo National de Estatisticas y Censos. Registro Estadístico De Camas y Egresos Hospitalarios 20192020 [Available from: https://www.ecuadorencifras. gob.ec/documentos/web-inec/Estadisticas_Sociales/Camas_Egresos_Hospitala rios/Cam_Egre_Hos_2019/Presentacion\%20ECEH_2019.pdf.

36. Institudo National de Estatisticas y Censos. Anuario de estadísticas de salud: Camas y egresos hospitalarios 2019. 2020.

37. Lu R, Zhao X, Li J, Niu P, Yang B, Wu H, et al. Genomic characterisation and epidemiology of 2019 novel coronavirus: implications for virus origins and receptor binding. Lancet. 2020;395(10224):565-74. https://doi.org/10.1016/ S0140-6736(20)30251-8.

38. Afsar B, Kanbay M, Afsar RE. Hypoxia inducible factor-1 protects against COVID-19: a hypothesis. Med Hypotheses. 2020;143:109857. https://doi.org/1 0.1016/j.mehy.2020.109857.

39. Millet GP, Debevec T, Brocherie F, Burtscher M, Burtscher J. Altitude and COVID-19: friend or foe? A narrative review. Physiol Rep. 2021;8(24):e14615. https://doi.org/10.14814/phy2.14615.

40. Soliz J, Schneider-Gasser EM, Arias-Reyes C, Aliaga-Raduan F, PomaMachicao L, Zubieta-Calleja G, et al. Coping with hypoxemia: could erythropoietin (EPO) be an adjuvant treatment of COVID-19? Respir Physiol Neurobiol. 2020;279:103476. https://doi.org/10.1016/j.resp.2020.103476.

41. Elvis AM, Ekta JS. Ozone therapy: a clinical review. J Nat Sci Biol Med. 2011; 2(1):66-70. https://doi.org/10.4103/0976-9668.82319.

42. Yao M, Zhang L, Ma J, Zhou L. On airborne transmission and control of SARS-Cov-2. Sci Total Environ. 2020;731:139178. https://doi.org/10.1016/j. scitotenv.2020.139178

43. Duan SM, Zhao XS, Wen RF, Huang JJ, Pi GH, Zhang SX, et al. Stability of SARS coronavirus in human specimens and environment and its sensitivity to heating and UV irradiation. Biomed Environ Sci. 2003;16(3):246-55. 
44. Yao Y, Pan J, Liu Z, Meng X, Wang W, Kan H, et al. No association of COVID19 transmission with temperature or UV radiation in Chinese cities. Eur Respir J. 2020;55(5).

45. Rondanelli M, Miccono A, Lamburghini S, Avanzato I, Riva A, Allegrini P, et al. Self-Care for Common Colds: the pivotal role of vitamin D, vitamin C, zinc, and Echinacea in three Main immune interactive clusters (physical barriers, innate and adaptive immunity) involved during an episode of common colds-practical advice on dosages and on the time to take these nutrients/botanicals in order to prevent or treat common colds. Evid Based Complement Alternat Med. 2018;2018:5813095-36. https://doi.org/10.1155/2 018/5813095.

46. Yamshchikov AV, Desai NS, Blumberg HM, Ziegler TR, Tangpricha V. Vitamin $D$ for treatment and prevention of infectious diseases: a systematic review of randomized controlled trials. Endocr Pract. 2009;15(5):438-49. https://doi. org/10.4158/EP09101.ORR

47. Gunville CF, Mourani PM, Ginde AA. The role of vitamin D in prevention and treatment of infection. Inflamm Allergy Drug Targets. 2013;12(4):239-45. https://doi.org/10.2174/18715281113129990046.

48. Jolliffe DA, Griffiths CJ, Martineau AR. Vitamin D in the prevention of acute respiratory infection: systematic review of clinical studies. J Steroid Biochem Mol Biol. 2013;136:321-9. https://doi.org/10.1016/j.jsbmb.2012.11.017.

49. Razdan K, Singh K, Singh D. Vitamin D levels and COVID-19 susceptibility: is there any correlation? Med Drug Discov. 2020;7:100051. https://doi.org/10.1 016/j.medidd.2020.100051.

50. Marik PE, Kory P, Varon J. Does vitamin D status impact mortality from SARS-CoV-2 infection? Med Drug Discov. 2020;6:100041. https://doi.org/10.1 016/j.medidd.2020.100041.

51. Stephens KE, Chernyavskiy P, Bruns DR. Impact of altitude on COVID-19 infection and death in the United States: a modeling and observational study. PLoS One. 2021;16(1):e0245055. https://doi.org/10.1371/journal.pone. 0245055.

52. Arias-Reyes C, Carvajal-Rodriguez F, Poma-Machicao L, Aliaga-Raduan F, Marques DA, Zubieta-DeUrioste N, et al. Decreased incidence, virus transmission capacity, and severity of COVID-19 at altitude on the American continent. PLoS One. 2021;16(3):e0237294. https://doi.org/10.1371/journal. pone.0237294

53. Fernandes JSC, da Silva RS, Silva AC, Villela DC, Mendonca VA, Lacerda ACR. Altitude conditions seem to determine the evolution of COVID-19 in Brazil. Sci Rep. 2021;11(1):4402. https://doi.org/10.1038/s41598-021-83971-x.

54. Thomson TM, Casas F, Guerrero HA, Figueroa-Mujica R, Villafuerte FC, Machicado C. Potential protective effect from COVID-19 conferred by altitude: a longitudinal analysis in Peru during full lockdown. High Alt Med Biol. 2021;22(2):209-24. https://doi.org/10.1089/ham.2020.0202.

55. Burtscher J, Burtscher M, Millet GP. Caution is needed on the effect of altitude on the pathogenesis of SAR-CoV-2 virus. Respir Physiol Neurobiol. 2020:279:103464. https://doi.org/10.1016/.j.esp.2020.103464.

56. Burtscher M. Lower mortality rates in those living at moderate altitude. Aging (Albany NY). 2016;8(10):2603-4. https://doi.org/10.18632/aging.101 057.

57. Faeh D, Gutzwiller F, Bopp M. Swiss National Cohort Study G. lower mortality from coronary heart disease and stroke at higher altitudes in Switzerland. Circulation. 2009;120(6):495-501. https://doi.org/10.1161/ CIRCULATIONAHA. 108.819250.

58. Millet GP, Debevec T, Brocherie F, Malatesta D, Girard O. Therapeutic use of exercising in hypoxia: promises and limitations. Front Physiol. 2016;7:224. https://doi.org/10.3389/fphys.2016.00224.

59. Gupta A, Pradhan B, Maulud KNA. Estimating the impact of daily weather on the temporal pattern of COVID-19 outbreak in India. Earth Systems and Environment. 2020:4(3):523-34. https://doi.org/10.1007/s41748-020-00179-1.

60. Ma Y, Zhao Y, Liu J, He X, Wang B, Fu S, et al. Effects of temperature variation and humidity on the death of COVID-19 in Wuhan. China Science of The Total Environment. 2020;724:138226. https://doi.org/10.1016/j. scitotenv.2020.138226

\section{Publisher's Note}

Springer Nature remains neutral with regard to jurisdictional claims in published maps and institutional affiliations.

Ready to submit your research? Choose BMC and benefit from:

- fast, convenient online submission

- thorough peer review by experienced researchers in your field

- rapid publication on acceptance

- support for research data, including large and complex data types

- gold Open Access which fosters wider collaboration and increased citations

- maximum visibility for your research: over $100 \mathrm{M}$ website views per year

At BMC, research is always in progress.

Learn more biomedcentral.com/submissions 